\title{
Cannibalism, among Other Solutions of Adaption, in Habitats Where Food Is Not Available for Salamandra infraimmaculata Larvae Diet in Breeding Places in Xeric Habitats
}

\author{
Gad Degani ${ }^{1,2}$ \\ ${ }^{1}$ MIGAL-Galilee Technology Center, Kiryat Shmona, Israel \\ ${ }^{2}$ School of Science and Technology, Tel Hai Academic College, Upper Galilee, Israel \\ Email: gad@migal.org.il
}

Received 15 October 2015; accepted 12 January 2016; published 15 January 2016

Copyright (C) 2016 by author and Scientific Research Publishing Inc.

This work is licensed under the Creative Commons Attribution International License (CC BY).

http://creativecommons.org/licenses/by/4.0/

\section{(c) (i) Open Access}

\begin{abstract}
The present study examines the inherent flexibility in the feeding responses of $\boldsymbol{S}$. infraimmaculata larvae to various breeding places. In addition, the study examines the hypothesis that in dry conditions, the water breeding places are the limiting factor for the survival and completion of the life cycle of populations of $S$. infraimmaculata. In the breeding sites, the food for larvae is not available, and cannibalism is the specific adaptation for larvae to grow and complete metamorphosis. $S$. infraimmaculata larvae feed on various invertebrates in different habitats, and cannibalism involves the adaptation to breeding places where food is not available. The growth only by cannibalism as the only way to adapt to these habitats because no food is found in breeding places at the southern border of its distribution is described here for the first time, not only in salamanders but in other animals as well.
\end{abstract}

\section{Keywords}

Cannibalism, Habitats, Salamandra

\section{Introduction}

Numerous species belonging to the genus Salamandra can be found throughout Europe, North Africa and East

How to cite this paper: Degani, G. (2016) Cannibalism, among Other Solutions of Adaption, in Habitats Where Food Is Not Available for Salamandra infraimmaculata Larvae Diet in Breeding Places in Xeric Habitats. Open Journal of Animal Sciences, 5, 31-41. http://dx.doi.org/10.4236/ojas.2016.61005 
Asia, surviving in various habitats and climates [1] [2]. Steinfartz et al. [3] suggested that five major monophyletic groups exist in Europe (S. salamandra, S. infraimmaculata, S. corsica, S. atra, and S. lanzai), the S. algira was located in Africa [4], and later studies suggested that the genus Salamandra included six distinct species [3].

Salamanders in Israel belong to S. infraimmaculata. S. infraimmaculata, and like many other amphibians, possess complex life cycles; the cycle consists of free-living aquatic larvae that metamorphose into terrestrial adults under relatively extreme conditions in various habitats [1]. For more than 35 years [1], many aspects of the adaptation of $S$. infraimmaculata habitats have been studied in northern Israel by comparing the isolated populations.

$S$. infraimmaculata populations found in northern Israel are located near breeding sites in three different and isolated areas: (1) Mount Carmel; (2) Galilee (Upper Galilee and Western Galilee); and (3) Mount Hermon [5].

Differences in physiological, morphological and biological adaptation [6] [7] exist among these isolated populations of salamanders that are affected by habitat conditions [1] [8] [9]. Various types of breeding sites are situated in these three different regions in Israel [10] [11]. The relatively drier areas of Mount Carmel and the central Galilee have permanent (i.e., springs and streams) and seasonal (i.e., temporal ponds and rain pools) breeding sites [12] [13]. Many types of breeding sites exist in xeric areas, including streams, springs, rock pools, rain pools and large ponds, where water is available during different time periods and under various conditions [11].

Northern Israel, similar to other Mediterranean regions, is characterized by a rather short rainy season that is unpredictable in duration and magnitude between November-January when about $66 \%$ of the rain falls [14]. Since the rainy season is followed by eight months of hot-dry weather, breeding has to take place by January at the latest or the metamorphosing larvae will die. This may be explained by the colonization of new habitats by salamanders living terrestrially in xeric habitats, where breeding locations are limited. Some of the breeding places are in caves or rock pool holes where darkness prevails and primary production is very low, and no invertebrates are available as food for larvae growth and completion of metamorphosis [11] [15] [16]. In S. infraimmaculata larvae, cannibalism was observed immediately after birth and during growth under laboratory conditions, the larger larvae devouring the smaller ones. A relatively large number of papers have been published on S. infraimmaculata larvae cannibalism under artificial or semi-artificial conditions (Degani, 1993; Degani et al., 1980; Buckley et al., 2007; Warburg, 2012; Sadeh et al., 2009; Cohen et al., 2006). However, very little information has been published on cannibalism in natural habitats, although food is limited in some of the larvae habitats of S. infraimmaculata. Moreover, some information supports the hypothesis that agnatic variations exist among isolated populations in northern Israel and perhaps cannibalism in natural habitats is one specific adaptation [17] [18]. No information is available on the genetic variation larvae.

The present study examined the hypothesis that in the natural habitat of $S$. infraimmaculata, the number of breeding water bodies was limited for salamander to complete the life cycle, and the breeding sites and food supply might be a bottleneck for populations of S. infraimmaculata [11] [16] [19], Cannibalism helped in the adaptation of this species to the habitats by using the breeding sites in which food was not available or limited in order for them to survive.

\section{Materials and Methods}

\subsection{Study Area}

The different types of breeding sites of $S$. infraimmaculata populations in northern Israel, namely winter pools, springs and streams, were sampled: three Tel Dan streams, where water is available all year round; the Sasa pond, where water is available during winter and spring; the Sasa rock pool, where water is available all year round; the Gush Halav pond, where food (invertebrates and primary production) is readily available; and the Hammama cave spring, where no food is available and the primary production is very low [11] [16] [19] (Table 1). All of the breeding sites of $S$. Infraimmaculata were described by Degani [1].

1) Gush Halav pond. A temporary winter rain pool containing water from December to March/April during winter. Temperature range $1^{\circ} \mathrm{C}$ to $25^{\circ} \mathrm{C}$, depth $10-80 \mathrm{~cm}$, area $10 \times 20 \mathrm{~m}, 725 \mathrm{~m}$ above sea level.

2) Sasa pond. Relatively large winter pond containing water from November/December to June/August. Temperature range $1^{\circ} \mathrm{C}$ to $26^{\circ} \mathrm{C}$, depth $20-100 \mathrm{~cm}$, area $40 \times 60 \mathrm{~m}$.

3) Sasa rock pool. Retains water for 7 - 12 months. Temperature range $5^{\circ} \mathrm{C}$ to $22^{\circ} \mathrm{C}$, depth $100 \mathrm{~cm}$, area $2 \times 6$ $\mathrm{m}$.

4) Hammama cave spring. Small spring originating in a small dark cave and forming a small pool inside the cave. Temperature range $9^{\circ} \mathrm{C}$ to $16^{\circ} \mathrm{C}$, depth $6-20 \mathrm{~cm}$, area $1 \times 20 \mathrm{~m}$.

5) Tel Dan stream. Fast-flowing stream. Temperature range $15^{\circ} \mathrm{C}$ to $17^{\circ} \mathrm{C}$, depth $5-100 \mathrm{~cm}$. 
Table 1. Amphibian larvae breeding sites in this study.

\begin{tabular}{ccccc}
\hline Name & Type & Latitude & Longitude & Height (m.a.s.l.) \\
\hline Tel Dan & Stream & 211,100 & 294,800 & 190 \\
Gush Halav & Winter pond & 240,044 & 269,332 & 270,855 \\
Sasa & Pond & 186,972 & 276,819 & 810 \\
Hammama & Cave spring & 187,299 & 270,855 & 800 \\
Sasa & Rock pool & 186,972 & 820 \\
\hline
\end{tabular}

\subsection{Larvae Samples}

The larval collection period is the time when larvae are found in the breeding places during the winter as described by Goldberg et al. (2009a). In this study, the period was adjusted by \pm 30 days according to the frequency at which we arrived at the breeding sites. Once every four weeks, 10 larvae of $S$. infraimmaculata from a depth of approximately $10-120 \mathrm{~cm}$ were captured with a dip-net. This capture was made at any time at three different points in the pool (with a total of about 15 individuals per species) [20]. The full length of each larvae was measured with calipers $( \pm 0.5 \mathrm{~mm})$, and each larvae was immediately released at the point of capture without marking. Since the salamander is a protected species in Israel, permits for collecting and dissecting larvae for stomach analyses were obtained, courtesy of the Nature Reserves Authority. Larvae were collected in batches of five, preserved in $70 \%$ ethylalcohol and later dissected. Altogether, the stomach contents of 140 larvae were examined. In addition to the salamanders' larvae collected, samples of aquatic invertebrates were also collected from the same localities using a $11 \times 17 \mathrm{~cm}$ hand-net with $1 / 3 \mathrm{~mm}$ holes. The net was moved 10 times near the bottom over an area of $1 \mathrm{~m}$. The invertebrates were preserved and stored in $100 \mathrm{ml}$ of $70 \%$ ethylalcohol until examination. Three $\mathrm{ml}$ of preserved samples were taken for identification of the specimens.

\subsection{Experiment under Laboratory Conditions}

The importance of the experiment in the laboratory is to make observations in the natural habitats regarding how cannibalistic larvae can grow and metamorphose only through cannibalism without any other food.

Ten large cannibalistic larvae from the Hammama cave spring were maintained under experimental conditions in the laboratory and divided into two groups (five larvae per group) in the same aquarium measuring $30 \times$ $25 \times 32 \mathrm{~cm}$. Fifteen small larvae from the Hammama cave spring were added to one group, and each day the number of small larvae that were eaten by the large larvae (cannibalistic larvae) were added. No other food was provided. The second group was left without food in order to examine if cannibalism occurred also among the large cannibalistic larvae.

\subsection{Statistical Analysis}

The following three parameters, larval length, weight and age, were analyzed by a one-way ANOVA, with the level of significance between groups set at $\mathrm{P}<0.05$. In addition, we compared the average length of larvae of $S$. infraimmaculata and the average age at metamorphosis in permanent and ephemeral breeding sites by a t-test. The calculated growth formulas for larvae that developed using rogation analysis: $y=a x 2+b x+c, y=a \ln x+$ $\mathrm{b}$ and $\mathrm{y}=$ aebx, [11] [16] [19] and the select formula was done according to the level of significance $(\mathrm{P}<0.05)$.

\section{Results}

The larvae of $S$. infraimmaculata are carnivores and they eat different invertebrates available in the water body (Table 2).

The inveterate food in the Sasa pond was Hemidiapous at the beginning of the winter and mostly almasyi, Ceriodaphnia and Chydoridae at the end of the winter. In the Hammama cave spring, cannibalism is the main food source for the cannibalistic larvae of $S$. infraimmaculata (Table 3, Figure 1), and only a few and not significant numbers of mosquito larvae (Culex) (Table 3) are found in summer or autumn. In the Gush Halav pond, crustaceans represent most of the salamanders' larvae.

The staple inveterate food in the Sasa pond was Hemidiapous at the beginning of the winter, and mostly almasyi, Ceriodaphnia and Chydoridae at the end of the winter. In the Hammama cave spring, cannibalism is the 
main food source for the cannibalistic larvae of S. infraimmaculata (Table 3, Figure 1), and only a few and not significant numbers of mosquito larvae (Culex) (Table 3) are found in summer or autumn. In the Gush Halav pond, crustaceans represent most of the salamanders' larvae.

In the Dan stream, the S. infraimmaculata larvae feed on crustaceans and the genus belonging to the species Malanopsis preamorsa that was found in the Dan stream all year round. Among the various habitats, the Hammama cave spring was the only breeding site in which cannibalistic larvae were found (Table 2). In other words, only in this habitat were the larvae in the stomach of $S$. infraimmaculata (cannibalistic) found (Figure 1).

The situation in the laboratory experiments, as illustrated in Figure 7, shows that cannibalistic larvae can grow and complete metamorphosis without any other food source, as was found in the Hammama cave spring.

The size of larvae in the various habitats is presented in Figures 2-6. In all of the habitats, the size of tadpoles increased from winter to summer but not in the Hammama cave spring, where mean length and weight did not change significantly. Small larvae existing together with large larvae during the entire growth period showed a situation whereby cannibalistic larvae fed on small larvae. The situation in the laboratory experiments, as illustrated in Figure 7, shows that cannibalistic tadpoles can grow and complete metamorphosis without any other food source, as was found in the Hammama cave spring.

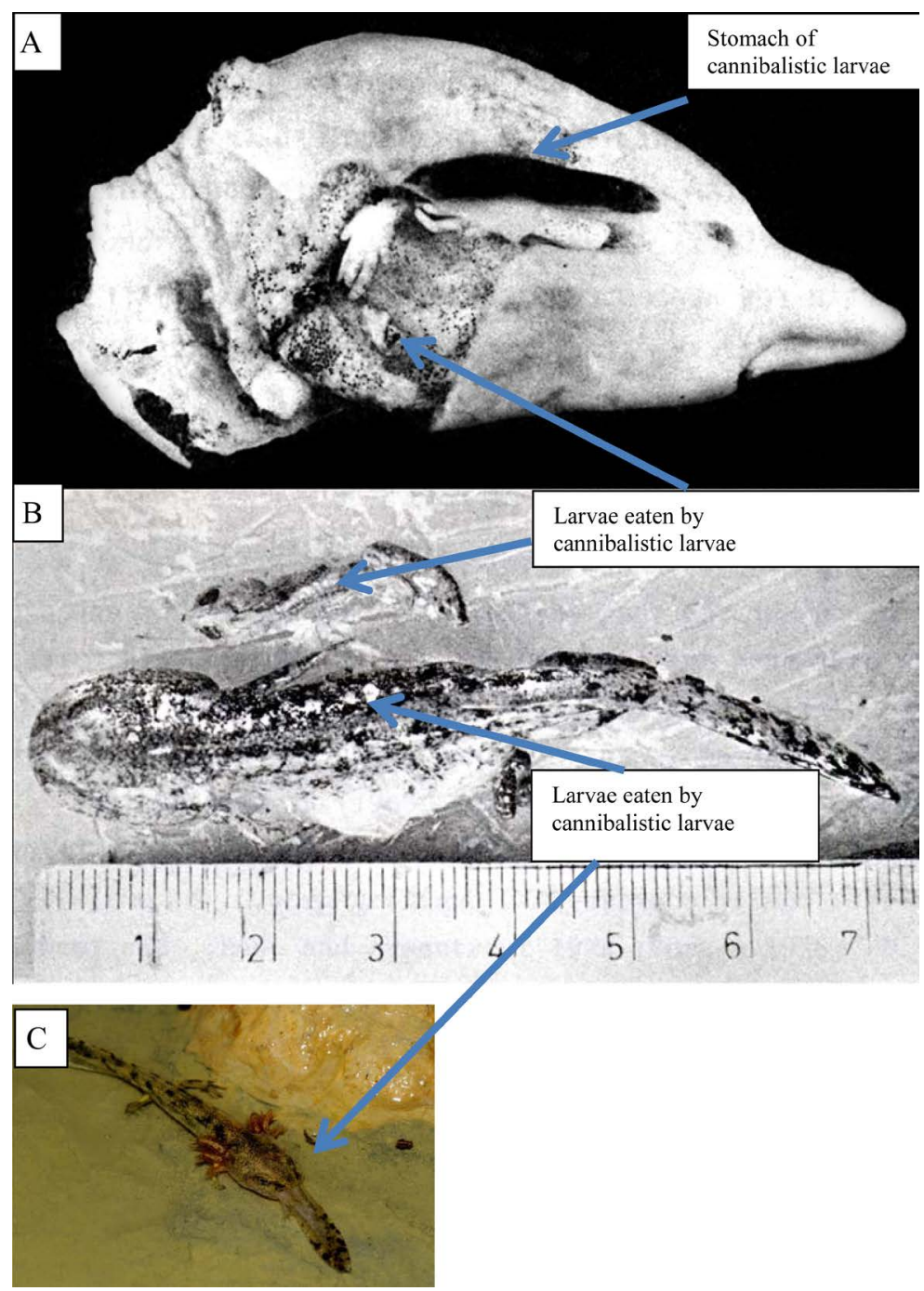

Figure 1. (A) Larvae inside the stomach of cannibalistic larvae of S. infraimmaculata from the Hammama spring; (B) Cannibalistic larvae and the larvae eaten by them from the Hammama spring; (C) Cannibalistic larvae swallow larvae in Hammama spring (photo by Dr. Jonathan C. Marshall). 
Table 2. The number of invertebrates groups found in the stomach of larvae at various breeding places ( $\mathrm{n}=10$ in each breeding site). The number in the table shows the number of invertebrates in the stomach of $S$. infraimmaculata larvae. The number of invertebrates in the stomach of larvae is different among the various breeding sites $(\mathrm{P}<0.05$, ANOVA).

\begin{tabular}{|c|c|c|c|c|c|}
\hline \multicolumn{6}{|c|}{ Breeding Sites of Salamanders larvae } \\
\hline & Sasa Pond & Gush Halav Pond & Sasa Rock Pool & Hammama Spring & Tel Dan Stream \\
\hline $\begin{array}{c}\text { Number of } \\
\text { larvae stomach analysis }\end{array}$ & 25 & 25 & 35 & 30 & 25 \\
\hline \multicolumn{6}{|l|}{ Aquatic invertebrates } \\
\hline Hemidiaptomus Gurney & 480 & 7 & 36 & & \\
\hline Potamocypris almasyi & 133 & & 18 & & \\
\hline Ceriodaphnia Sp. & 66 & 56 & 31 & & \\
\hline Chydoridae & 82 & & & & \\
\hline Oligochaeta & 1 & & & & \\
\hline Cypris pubera Jveniles & 12 & & & & \\
\hline Cypris pubera Adult & 30 & & & & \\
\hline Candona Sp. & 4 & & & & \\
\hline Arctodiaptomus similis & 7 & 1 & & & \\
\hline Dytiscid Larva & 1 & & & & \\
\hline Hemiptera Larvae & 2 & & & & \\
\hline Eucypris Sp. & 2 & & & & \\
\hline Chironomidae Larvae & 1 & 4 & & & \\
\hline Hemiptera & 1 & & & & \\
\hline Lynceus & & 341 & & & \\
\hline Cyzicus & & 3 & & & \\
\hline Eucypris Lutria & & 40 & & & \\
\hline Cyclops & & 2 & 6 & & \\
\hline Coleopter Larvae & & 1 & & & \\
\hline Melanopsis praemorsa & & & 6 & & 6 \\
\hline Ephemeroptera & & & 3 & & \\
\hline Daphnia & & & 3 & & \\
\hline Diaptomid & & & 3 & & \\
\hline Culex (larvae) & & & & 1 & \\
\hline Insecta & & & & 4 & \\
\hline S. (larvae) infraimmaculata & & & & 12 & \\
\hline Gammarus Sp. & & & & & 34 \\
\hline
\end{tabular}


Table 3. Aquatic invertebrates found at the breeding sites of $S$. infraimmaculata. There are significant differences in the number of invertebrates among the various breeding sites $(\mathrm{P}<0.05$ ANOVA).

\begin{tabular}{|c|c|c|c|c|c|}
\hline \multicolumn{6}{|c|}{ Breeding Sites of Salamanders larvae } \\
\hline & Sasa Pond & Gush Halav Pond & Sasa Rock Pool & $\begin{array}{l}\text { Hammama } \\
\text { Spring }\end{array}$ & Tel Dan Stream \\
\hline Number of Samples & 5 & 5 & 7 & 6 & 5 \\
\hline \multicolumn{6}{|l|}{ Aquatic invertebrates } \\
\hline Hemidiaptomus Gurney & 252 & 42 & 33 & & \\
\hline Potamocypris almasyi & 74 & & 314 & & \\
\hline Ceriodaphnia Sp. & 50 & 12 & 138 & & \\
\hline Chydoridae & 13 & & 32 & & \\
\hline \multicolumn{6}{|l|}{ Oligochaeta } \\
\hline \multicolumn{6}{|l|}{ Cypris pubera Jveniles } \\
\hline Cypris pubera Adult & 22 & & & & \\
\hline \multicolumn{6}{|l|}{ Candona Sp. } \\
\hline Arctodiaptomus similis & 5 & & & & \\
\hline Dytiscid Larva & 3 & & & & \\
\hline Hemiptera Larvae & 2 & & & & \\
\hline Euecypris Sp. & 3 & 14 & & & \\
\hline Chironomidae Larvae & 4 & 4 & 2 & & \\
\hline \multicolumn{6}{|l|}{ Hemiptera } \\
\hline \multicolumn{6}{|l|}{ Lynceus } \\
\hline Cyzicus Sp. & & 10 & & & \\
\hline \multicolumn{6}{|l|}{ EucyprisLutria } \\
\hline Cyclops & & 2 & 9 & & \\
\hline Coleopter Larvae & & 3 & & & \\
\hline Melanopsis praemorsa & & & 6 & & 7 \\
\hline Ephemeroptera & & & 1 & & \\
\hline Daphnia & & & 2 & & \\
\hline \multicolumn{6}{|l|}{ Diaptomid } \\
\hline Culex (larvae) & & & 5 & 6 & \\
\hline Insecta & 7 & & & & \\
\hline Corixa & & 3 & 5 & & \\
\hline Gammarus Sp. & & & & & 5 \\
\hline Lynceus Sp. & & 60 & & & \\
\hline Odonata larvae & & & & & 2 \\
\hline Ilydromus Sp. & & & & & 1 \\
\hline
\end{tabular}



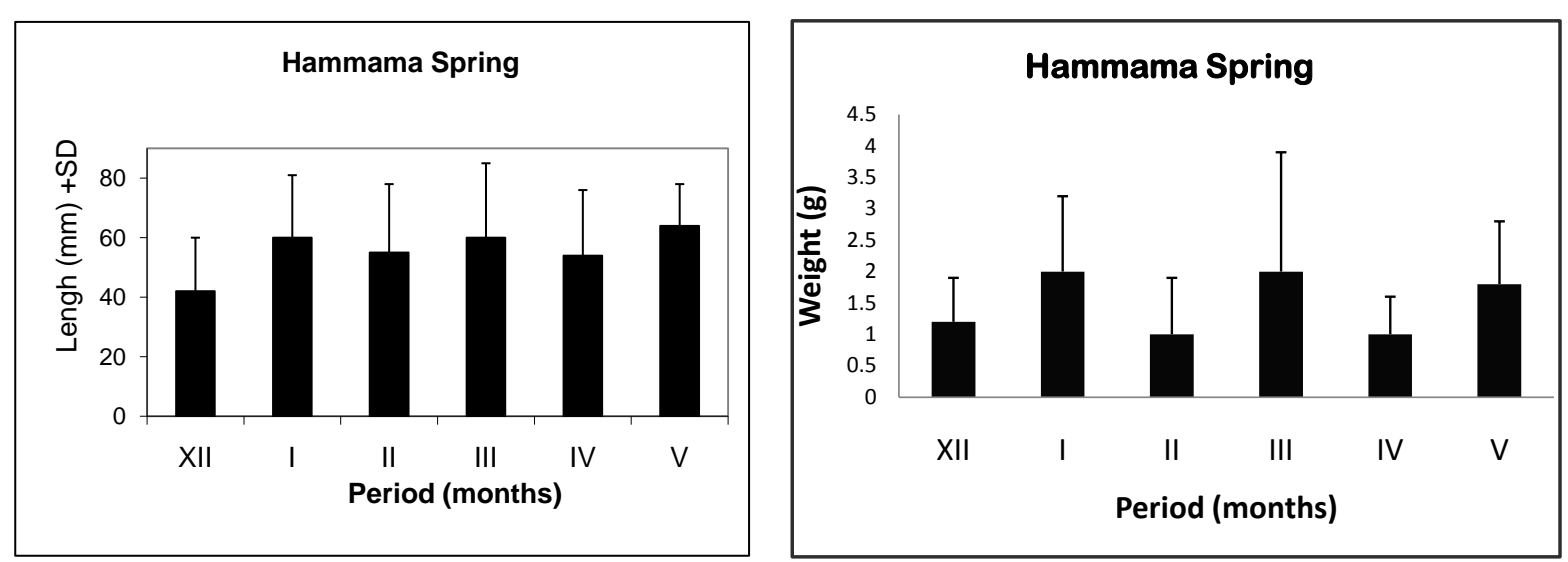

Figure 2. Size (length and weight) of larvae in the Hammama spring during growth and metamorphosis. The size of larvae in the various habitats is presented in Figures 2-6. In all of the habitats, the size of larvae increased significantly $(P<0.05$, ANOVA) from winter to summer but not in the Hammama cave spring, where mean length and weight did not change significantly. Small larvae existing together with large larvae during the entire growth period showed a situation whereby cannibalistic larvae fed on small larvae. The large standard deviation (SD) from the mean of larvae sizes was found (Figure 2) This situation was found in the stomach of large salamanders in the Hammama sparing (Figure 1). No significant differences were found between larvae size during the growth periods ( $\mathrm{P}>0.05$, ANOVA).
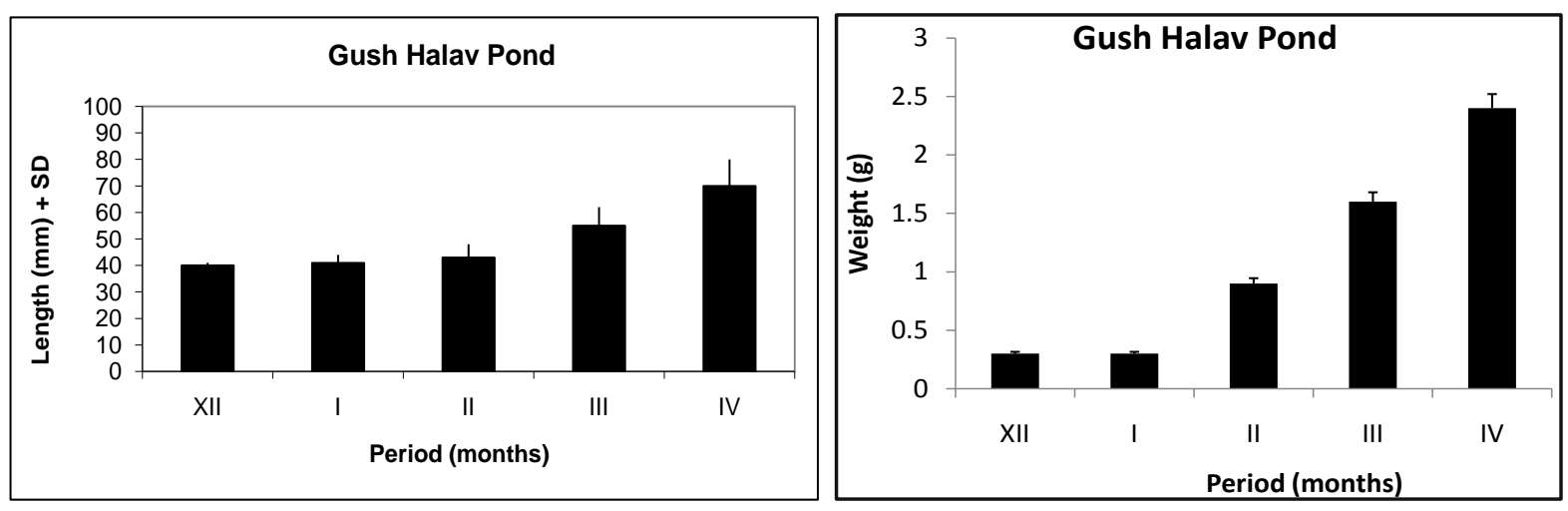

Figure 3. Size (length and weight) of larvae in the Gush Halav pond during growth and complete metamorphosis. Significant differences were found during the growth compared to the lengths at various times or weights at different larvae periods ( $\mathrm{P}<$ 0.05 , ANOVA). The calculated formula for length is $\mathrm{L}=2.71 \mathrm{X}^{2}-23.69 \mathrm{X}+91, \mathrm{R}^{2}=0.99$ and weight is $\mathrm{W}=1.21 \mathrm{X}^{2}-$ $12.78 \mathrm{X}+36, \mathrm{R}^{2}=0.99$.
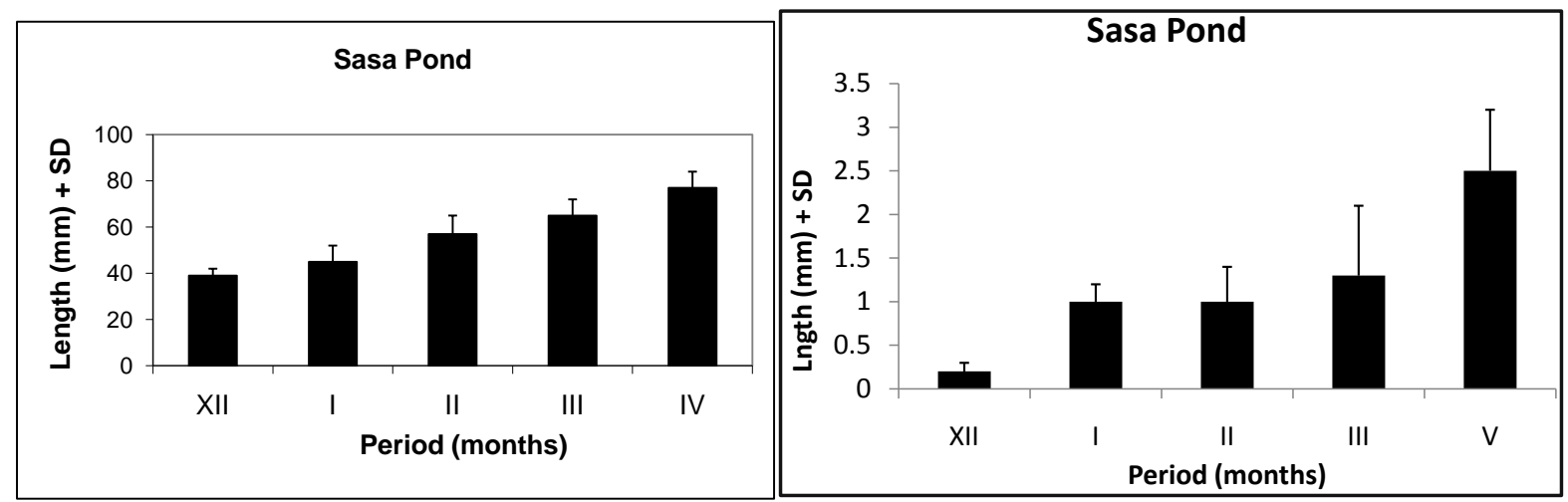

Figure 4. Size (length and weight) of larvae in the Sasa pond during growth and complete metamorphosis. Significant differences were found during the growth compared to the lengths at various times or weights at different larvae periods ( $\mathrm{P}<$ 0.05 , ANOVA). The calculated formula for length is $\mathrm{L}=0.57 \mathrm{X}^{2}-13.09 \mathrm{X}+89.4, \mathrm{R}^{2}=0.99$ and weight is $\mathrm{W}=0.29 \mathrm{X}^{2}-$ $6.31+27, \mathrm{R}^{2}=0.93$. 

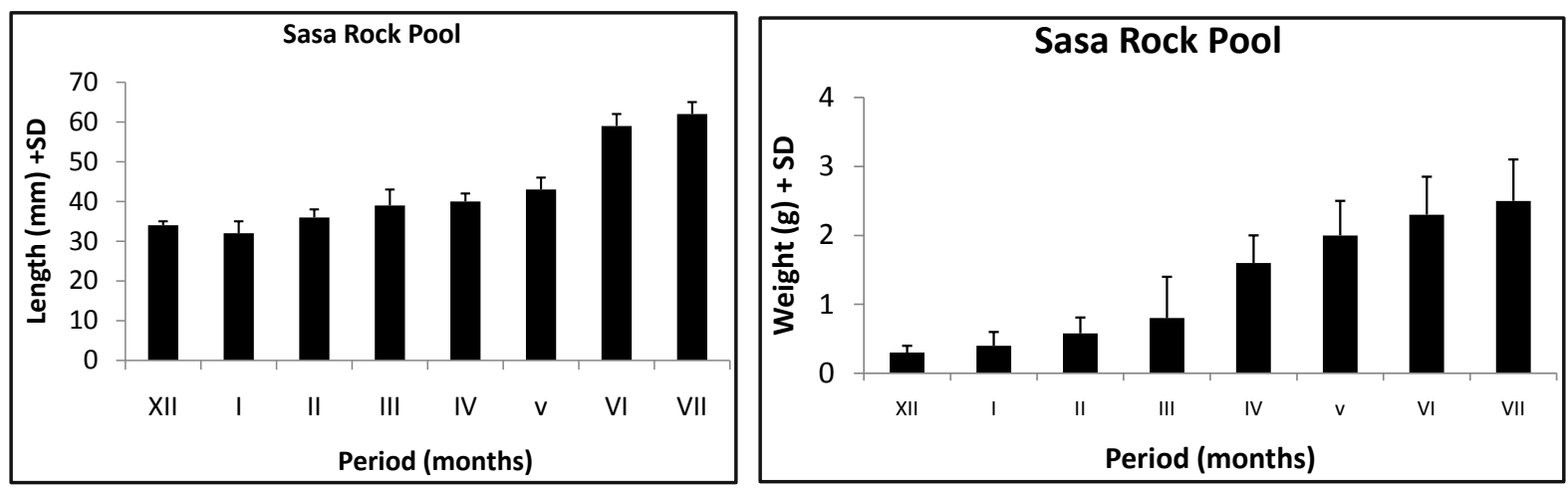

Figure 5. Size (length and weight) of larvae the Sasa rock pool during growth and complete metamorphosis. Significant differences were found during the growth in compared to the lengths at various times or weights at different larvae periods $(\mathrm{P}<0.05, \mathrm{ANOVA})$. The calculated formula for length is $L=0.98 X^{2}-12.40 X+77.55, R^{2}=0.97$ and weight is $W=0.02 X^{2}-0.56 X+3.55, R^{2}=0.98$.
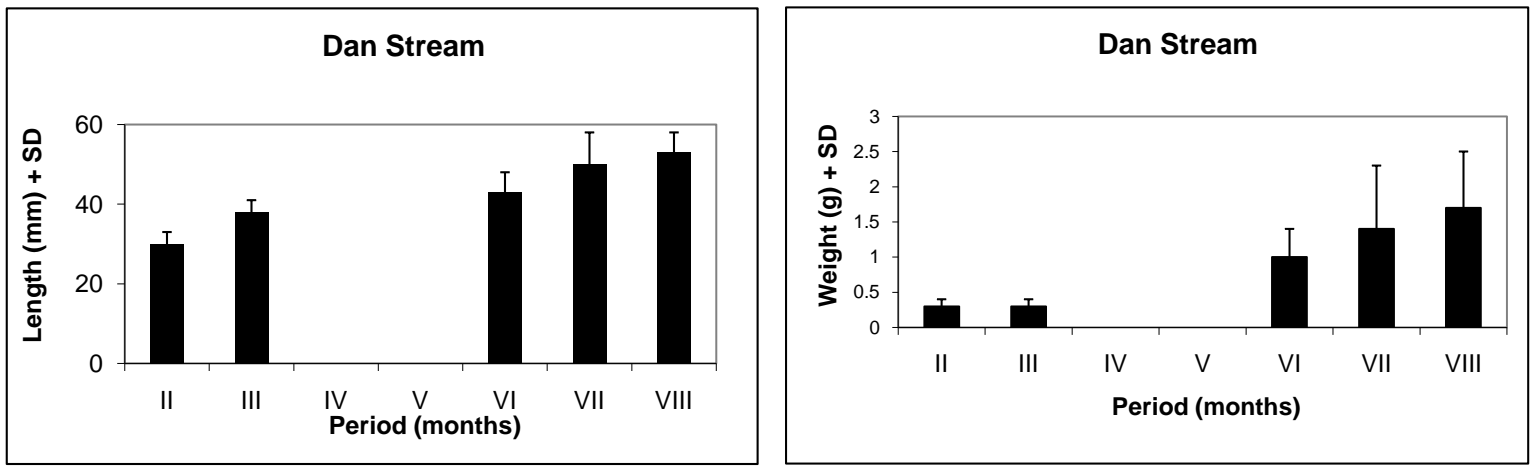

Figure 6. Size (length and weight) of larvae in the Dan stream during growth and complete metamorphosis. Significant differences were found during the growth in compared to the lengths at various times or the weights at different larvae periods $\left(\mathrm{P}<0.05\right.$, ANOVA). The calculated formula for length is $\mathrm{L}=0.035 \mathrm{X}^{2}-3.76 \mathrm{X}+56.41, \mathrm{R}^{2}=0.95$ and weight is $\mathrm{W}=0.03 \mathrm{X}^{2}$ $-0.49 \mathrm{X}+2.20, \mathrm{R}^{2}=0.99$.

\section{Discussion}

The present study demonstrated the inherent flexibility in the feeding responses of $S$. infraimmaculata larvae to several breeding places. This flexibility likely allows rapid adaptation to the varied ecological pressures of permanent or temporary habitats that are described in detail both for Urodela larvae and Aura [21], as well as other carnivore species including invertebrates [21] [22]. In the present study and others [16], various invertebrates are found with S. infraimmaculata larvae in many breeding places. However, to the best of our knowledge, no information is available on obligatory cannibalism without other food sources or primary production, since the mechanism of adaptation to a specific habitat, as described in the present study, in larvae growth in caves is described in S. infraimmaculata larvae in the present study.

In the natural semi-arid habitats of $S$. infraimmaculata characterized by relatively dry conditions [1], breeding places are very rare and not readily available. The flexibility of adaptation to various invertebrates food found in breeding sites and in the $S$. infraimmaculata larvae in the present study explain the ability of this species to adapt to various habitats, as described previously in several studies [11] [23] [24]. The specific habitats of larvae where food was not available, as revealed in the present study, is not well understood. Compared to a large number of papers describing the cannibalism of S. infraimmaculata larvae under experimental laboratory conditions (Degani, 1993; Degani et al., 1980; Buckley et al., 2007; Warburg, 2012; Sadeh et al., 2009; Cohen et al., 2006), no description of cannibalism in the habitats for this species has been made (include picture in the natural habitat Figure 1). The information based on laboratory studies suggested that cannibalism occurs in the natural habitats. At the southern limit of S. infraimmaculata distribution where breeding places are rare, rock pools and cave springs are used by salamanders for breeding, and cannibalism, among other solutions, is the only way to adapt to these habitats.

The advancement of cannibalism helps the larvae to grow and complete metamorphosis in habitats where 
food is not available. Based on previous studies (Degani et al., 1980; Degani 1993) and the results of the present study, the model of cannibalism development according to food availability (Figure 8) is proposed. In this situation, cannibalism involves the adaptation to habitats where partial or no food is available.
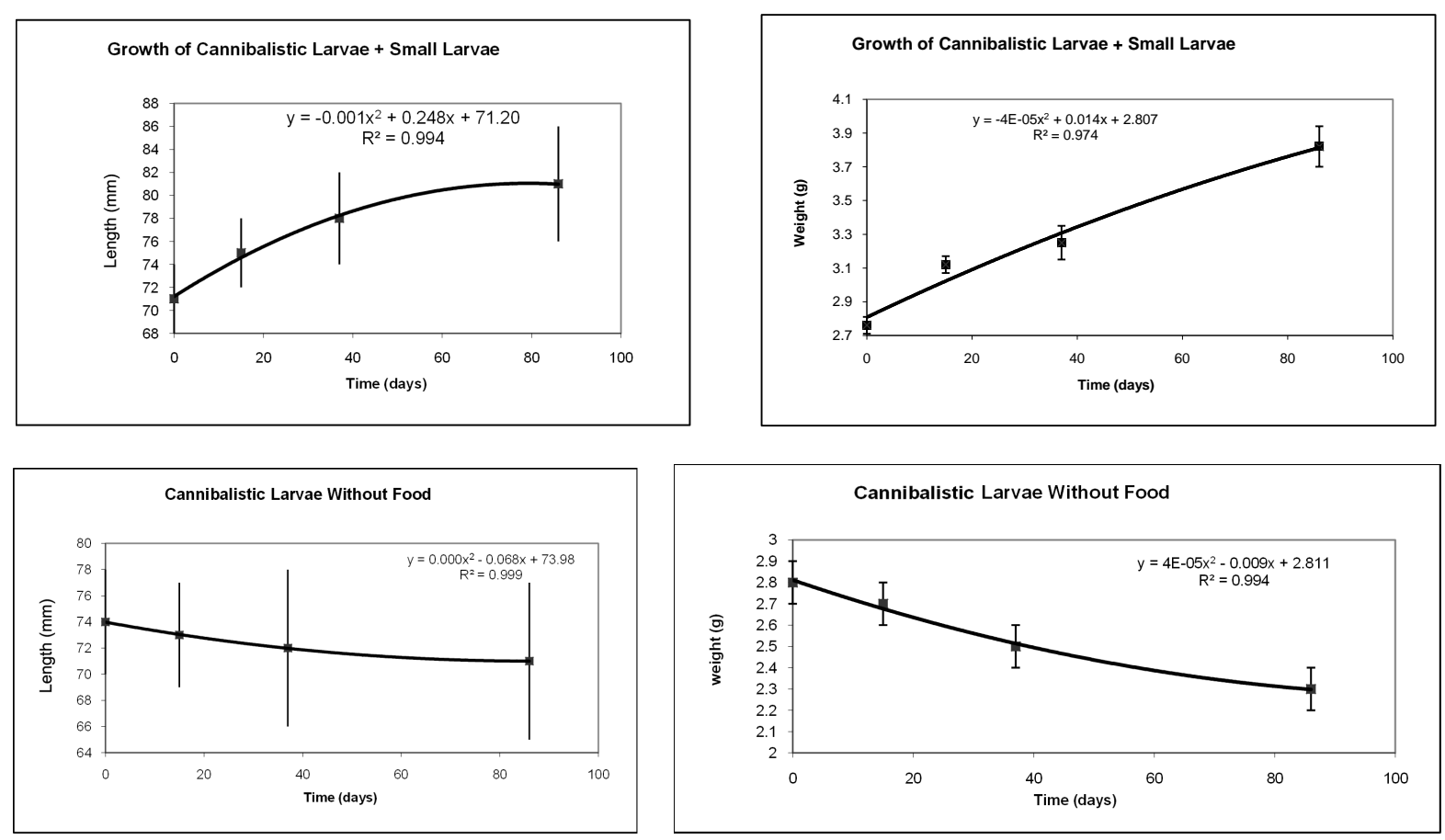

Figure 7. Size (length and weight) of cannibalistic larvae with and without small larvae and no invertebrates as food source.

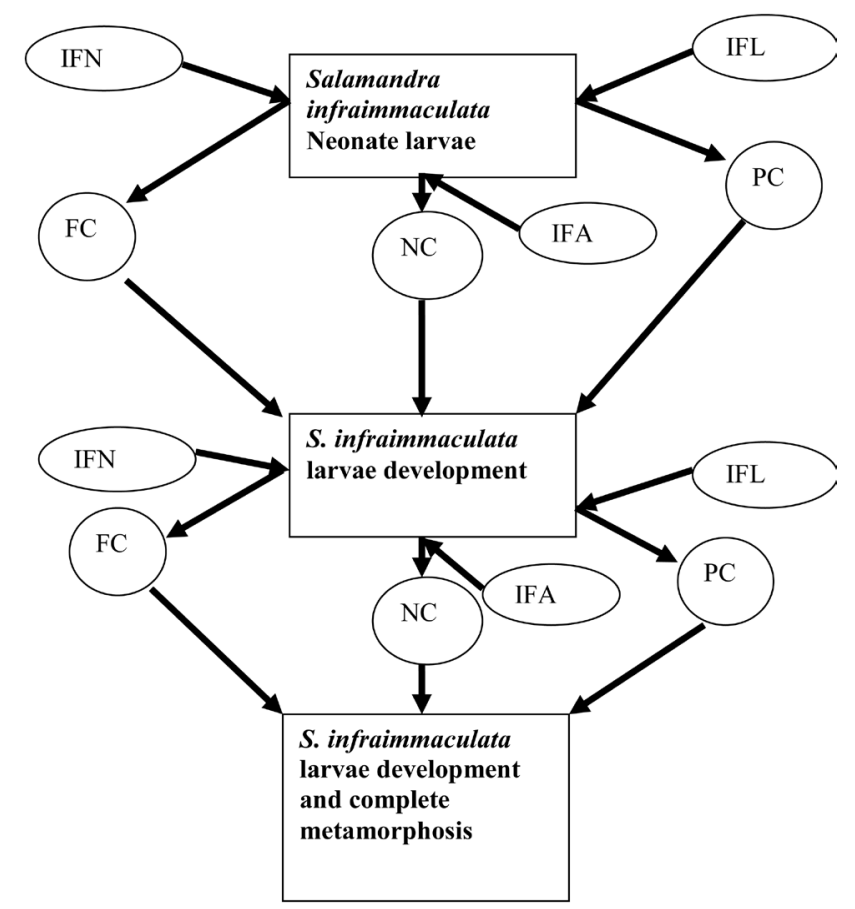

Figure 8. Model of the adaptation to xeric habitats by food and cannibalism development in Salamandra infraimmaculata. IFN = Invertebrates food not available, IFA = Unlimited invertebrates food available, IFL $=$ Limited invertebrates food available, NC $=$ No cannibalism (invertebrates food), PC = Partial cannibalism (larvae growth on cannibalism and invertebrates food, FC = Full cannibalism (larvae growth and development only on cannibalism). (Present study: Degani et al., 1980; Degani, 1993). 
The ability of $S$. infraimmaculata larvae found in various breeding places to adapt to different foods of $S$. infraimmaculata larvae [11] [16] is a very important phenomenon in terms of adaptation to various habitats. More detailed studies are required in order to determine if this adaptation in biological and genetic levels or in terms of flexibility is inherent in feeding responses. Several previous studies supported the hypothesis that variation exists among populations in different areas and habitats in many aspects, in addition to the food of larvae, as was found in the present study: morphology [8]; ecology adaptation of larvae growth and complete metamorphosis [10] [25]-[27]; behavior [28]-[30]; breeding [31]; physiology adaptation [6] [7] [32]-[35]; biological activity of metamorphosis salamanders [9] [36]; and molecular genetic variation (Blank et al., 2012; Degani, 1994; Degani et al., 1999; Goldberg et al., 2010; Goldberg et al., 2011a; Goldberg et al., 2011b).

\section{Conclusion}

In conclusion, among the various adaptations to different habitats described in this study, the suitability of various available foods is the main phenomenon to explain $S$. infraimmaculata survival in xeric habitats. Cannibalism is the only way to adapt to these habitats because no food is found in breeding places at the southern border of its distribution.

\section{References}

[1] Degani, G. (1996) The Salamander at the Southern Limit of Its Distribution. Laser Pages Publ. Ltd, Jerusalem.

[2] Vences, M., Sanchez, E., Hauswaldt, J.S., Eikelmann, D., Rodriguez, A., Carranza, S., Donaire, D., Gehara, M., Helfer, V., Lotters, S., Werner, P., Schulz, S. and Steinfartz, S. (2014) Nuclear and Mitochondrial Multilocus Phylogeny and Survey of Alkaloid Content in True Salamanders of the Genus Salamandra (Salamandridae). Molecular Phylogenetics and Evolution, 73, 208-216. http://dx.doi.org/10.1016/j.ympev.2013.12.009

[3] Steinfartz, S., Veith, M. and Tautz, D. (2000) Mitochondrial Sequence Analysis of Salamandra Taxa Suggests Old Splits of Major Lineages and Postglacial Recolonizations of Central Europe from Distinct Source Populations of Salamandra salamandra. Molecular Ecology, 9, 397-410. http://dx.doi.org/10.1046/j.1365-294x.2000.00870.x

[4] Escoriza, D., Comas, M.M., Donaire, D. and Carranza, S. (2006) Rediscovery of Salamandra algira Bedriaga, 1833 from the Beni Snassen Massif (Morocco) and Phylogenetic Relationships of North African Salamandra. Amphibia-Reptilia, 27, 448-455. http://dx.doi.org/10.1163/156853806778190042

[5] Veith, M., Degani, G. and Seitz, A. (1992) High Genetic Homogeneity of Salamandra salamandra (L.) in Israel. Zoologischer Anzeiger, 229, 63-72.

[6] Degani, G. (1981) The Adaptation of Salamandra salamandra (L.) from Different Habitats to Terrestrial Life. British Journal of Herpetology, 6, 169-172.

[7] Degani, G. (1981) Salinity Tolerance and Osmoregulation in Salamandra salamandra (L.) from Different Populations. Journal of Comparative Physiology, 145, 133-137. http://dx.doi.org/10.1007/BF00782604

[8] Degani, G. (1986) Plasma Protein and Morphology of Salamandra salamandra in Israel. Amphibia-Reptilia, 7, 105114. http://dx.doi.org/10.1163/156853886X00334

[9] Degani, G. and Warburg, M.R. (1976) Biological and Ecological Studies on the Salamander Salamandra salamandra. Israel Journal of Zoology, 25, 206-207.

[10] Degani, G. (1986) Growth and Behavior of Six Species of Amphibian Larvae in a Winter Pond in Israel. Hydrobiologia, 140, 5-10. http://dx.doi.org/10.1007/BF00006723

[11] Goldberg, T., Nevo, E. and Degani, G. (2009) Breeding Site Selection According to Suitability for Amphibian Larval Growth under Various Ecological Conditions in the Semi-Arid Zone of Northern Israel. Ecologia Mediterranea, 35, 65-74.

[12] Warburg, M.R. (1994) Population Ecology, Breeding Activity, Longevity, and Reproductive Strategies of Salamandra salamandra: An 18-Year Long Study of an Isolated Population on Mt. Carmel, Israel. Mertensiella, 4, 399-421.

[13] Warburg, M. (1992) Breeding Patterns in Fringe Population of Fire Salamanders, Salamandra salamandra. Journal of Herpetology, 2, 54-58.

[14] Warburg, M. (2007) Longevity in Salamandra infraimmaculata from Israel with a Partial Review of Life Expectancy in Urodeles. Salamandra, 43, 21-34.

[15] Degani, G., Sela, E., Henkin, Z., Korem, S., Goldberg, T. and Warburg, M.R. (2007) Movement to Rock Pool Hole Breeding Sites of Salamandra infraimmaculata during Colonization of New Breeding Places in Xeric Habitats. Salamandra, 43, 7-12. 
[16] Degan, G. and Goldberg, T. (2013) Aquatic Invertebrates in Different Bodies of Water in a Semi-Arid Zone. American Open Animal Science Journal, 1, 1-16.

[17] Degani, G., Jackson, K., Dosoretz, C. and Plotzky, Y. (1999) Molecular DNA Variation in Salamandra infraimmaculata from Different Habitats. Israel Journal of Zoology, 44, 239-246.

[18] Goldberg, T., Pearlson, O., Nevo, E. and Degani, G. (2009) Sequence Analysis of Mitochondrial DNA in Salamandra infraimmaculata Larvae from Populations in Northern Israel. South American Journal of Herpetology, 4, 268-274. http://dx.doi.org/10.2994/057.004.0310

[19] Goldberg, T., Nevo, E. and Degani, G. (2012) Amphibian Larval in Various Water Bodies in the Semi-Arid Zone. Zoological Studies, 51, 345-361.

[20] Heyer, W.R., Donnelly, M.A., McDiarmid, R.W., Hayek, L.C. and Foster, M.S. (1994) Measuring and Monitoring Biological Diversity Standard Methods for Amphibians. Smithsonian Institution Press, Washington DC.

[21] Crump, M.L. (1986) Cannibalism by Younger Tadpoles: Another Hazard of Metamorphosis. Copiea, 1986, $1007-1009$. http://dx.doi.org/10.2307/1445301

[22] Jackson, R.R. (1980) Cannibalism as a Factor in the Mating Strategy of the Jumping Spider Phidippus johnsoni (Araneae: Salticidae). Bulletin of the British Entomological Society, 5, 129-133.

[23] Warburg, M.R. (2009) Age and Size at Metamorphosis of Half-Sib Larvae of Salamandra infraimmaculata Born in the Laboratory and Raised Singly under Three Different Food Regimes. The Belgian Journal of Zoology, 139, 156-165.

[24] Degani, G. and Kaplan, D. (1999) Distribution of Amphibian Larvae in Israeli Habitats with Changeable Water Availability. Hydrobiologia, 405, 49-56. http://dx.doi.org/10.1023/A:1003796820900

[25] Degani, G. and Mendelssohn, H. (1981) Interaction of Amphibian Larvae in a Winter Rain Pond. Israel Journal of Zoology, 30, 99-100.

[26] Degani, G. (1982) Amphibian Tadpole Interaction in a Winter Pond. Hydrobiologia, 96, 3-8. http://dx.doi.org/10.1007/BF00006274

[27] Cohen, M., Yeheskely-Hayon, D., Warburg, M.R., Davidson, D., Halev, G. and Sharon, R. (2006) Differential Growth Identified in Salamander Larvae Half-Sib Cohorts: Survival Strategy? Development, Growth and Differentiation, 48, 537-548. http://dx.doi.org/10.1111/j.1440-169X.2006.00887.x

[28] Degani, G. and Mendelssohn, H. (1981) Moisture as a Factor Influencing Selection of Hiding Places by Juvenile Salamandra-salamandra from Semi Arid Habitats. In: Shuval, H.I., Ed., International Meeting of the 12th Scientific Meeting of the Israel Ecological Society, Balaban International Science Services, Philadelphia, Jerusalem, 49-56.

[29] Degani, G. and Mendelssohn, H. (1982) Seasonal Activity of Salamandra salamandra (L.) (Amphibia, Urodela) in Headwaters of the Jordan River. Israel Journal of Zoology, 31, 77-85.

[30] Degani, G. (1984) Temperature Selection in Salamandra-salamandra Larvae and Juveniles from Different Habitats. The Biology of Behaviour, 9, 175-183.

[31] Degani, G. and Warburg, M. (1995) Variation in Brood Size and Birth Rates of Salamandra salamandra (L.) (Amphibia, Urodela) from Different Habitats in Northern Israel. Amphibia-Reptilia, 16, 341-349. http://dx.doi.org/10.1163/156853895X00424

[32] Degani, G., Sharon, R. and Warburg, M. (1997) Ovarian Steroid Levels in Salamandra salamandra Infraimmaculata during the Reproductive Cycle. General and Comparative Endocrinology, 106, 356-360. http://dx.doi.org/10.1006/gcen.1997.6883

[33] Degani, G. (1994) Ecophysiology of Salamandra salamandra at the Southern Limit of Its Distribution. Mertensiella, 4, 111-124.

[34] Degani, G. (1985) Water Balance and Body Fluids of Salamandra-salamandra (L.) in Their Natural Habitats in Summer and Winter. Comparative Biochemistry and Physiology Part A, 82, 479-482. http://dx.doi.org/10.1016/0300-9629(85)90885-0

[35] Degani, G. (1982) Water Balance of Salamanders Salamandra-salamandra from Different Habitats. Amphibia-Reptilia, 2, 309-314. http://dx.doi.org/10.1163/156853882X00220

[36] Degani, G. and Warburg, M.R. (1978) Population Structure and Seasonal Activity of the Adult Salamandra salamandra (L.) (Amphibia, Urodela, Salamandridae) in Israel. Journal of Herpetology, 12, 437-444.

http://dx.doi.org/10.2307/1563347 